\title{
Copepod feeding selectivity on microplankton, including the toxigenic diatoms Pseudo-nitzschia spp., in the coastal Pacific Northwest
}

\author{
M. Brady Olson ${ }^{1,2, *}$, Evelyn J. Lessard ${ }^{1}$, Chung Huen J. Wong ${ }^{1}$, Megan J. Bernhardt ${ }^{1}$ \\ ${ }^{1}$ School of Oceanography, University of Washington, Seattle, Washington 98225, USA \\ ${ }^{2}$ Present address: College of Marine Science, University of South Florida, St. Petersburg, Florida 33701, USA
}

\begin{abstract}
As part of the Pacific Northwest ECOHAB project, we measured clearance rates and feeding selectivity of calanoid copepods off the coast of Washington State, USA, during fall of 2003. We tested the hypothesis that copepods discriminate amongst prey, particularly against the toxic diatoms Pseudonitzschia spp. in natural assemblages from this highly productive, upwelling environment. Seven grazing experiments were conducted across and along the shelf using the copepods Calanus pacificus, Metridia pacifica, Acartia longiremis and a small community assemblage dominated by Acartia spp., with minor contributions from Pseudocalanus spp., Paracalanus spp. and Oithona spp. Three general patterns emerged from our experiments. First, all copepods, except A. longiremis in 1 experiment, showed neutral preference or discriminated against Pseudo-nitzschia, but preference did not appear related to cellular domoic acid concentrations. Second, the dominant prey biomass contributors in each experiment were cleared at low rates relative to other prey types. In most cases the dominants were the diatom Thalassiosira spp. or the autotrophic dinoflagellates Ceratium spp. and Prorocentrum spp. The third pattern was high preference for microzooplankton. High clearance on microzooplankton can result in trophic cascades, which were evident in our size-fractionated chlorophyll data. These patterns indicate that copepods could have both direct and indirect effects on the plankton community composition on the Washington coast. However, our estimates of total potential grazing suggest that copepod grazing impact on Pseudo-nitzschia populations is negligible.
\end{abstract}

KEY WORDS: Copepod grazing $\cdot$ Prey selectivity $\cdot$ Pseudo-nitzschia $\cdot$ Microzooplankton

\section{INTRODUCTION}

Toxigenic diatoms in the genus Pseudo-nitzschia are widespread off the Washington coast where unique oceanographic characteristics (MacFadyen et al. 2005) appear to promote their growth, bloom formation, retention and toxicity (Horner et al. 2000, Trainer et al. 2002). At least 7 species of Pseudo-nitzschia have been found to occur on the Washington coast (Stehr et al 2002). Not all Pseudo-nitzschia spp. produce the marine neurotoxin domoic acid (DA), and for those that do, production of DA varies spatially and temporally (Trainer et al. 2002). The stimulus that induces DA production in the field remains ambiguous; there is evidence for increased DA production under phosphate and silicate limitation (e.g. Fehling et al. 2004), the presence of bacteria (Bates et al. 1995), elevated $\mathrm{pH}$ (Lundholm et al. 2004) and trace metal concentration (Maldonado et al. 2002).

Pseudo-nitzschia spp. are often the sole diatoms remaining after the spring and summer upwelling-induced diatom bloom events, and are found co-occurring and proliferating with taxa identified as members typical of 'recycled nutrient' communities (e.g. autotrophic dinoflagellates). Their wide spatial distribution, and more specifically, their long retention in the surface layer in diverse environmental conditions, implies that either reduced mortality rates, unique nutrient acquisition strategies (Wells et al. 2005), or both, play a significant role in the population ecology of these diatoms. 
As with any alga, the formation of a Pseudo-nitzschia bloom depends on imbalance that favors phytoplankton growth over mortality rate (Banse 1994). Once a bloom forms and exponential growth ceases, the retention and maintenance of the bloom in the water column becomes a near exclusive function of mortality rate. Pseudo-nitzschia is one of the few phytoplankton genera that are consistent and prevalent members of the global plankton community (Rhodes 1998, Cusack et al. 2002, Kaczmarska et al. 2005); this suggests that the balance between growth and mortality is consistently biased in favor of the former. In order to understand the population dynamics of Pseudo-nitzschia it is therefore important to study not only the factors that influence rates of cell division, but also the rates and relevant agents of mortality. Arguably, the most significant source of external mortality to phytoplankton is zooplankton grazing (Calbet \& Landry 2004). Consequently, any exploration of Pseudo-nitzschia mortality should start there.

Potential grazers of Pseudo-nitzschia spp. include the calanoid copepods. Unfortunately, our confidence in the knowledge that copepods will unreservedly graze on Pseudo-nitzschia is poor; to date no field experiments have explored this relationship in detail. Some copepods are selective feeders, discriminating prey based on a multitude of factors. Laboratory studies have established some of these factors to be size (Frost 1972), food quality (e.g. Cowles et al. 1988), chemical cues (Huntley et al. 1986) and toxin content of the prey (e.g. Teegarden 1999). These findings would suggest that, when offered a diverse prey suite, discriminate feeding by copepods may shape both microplankton community size structure and species composition. However, the degree to which selective grazing behavior shapes natural communities remains contradictory (Huntley 1982, Turner \& Tester 1989, Meyer-Harms et al. 1999, Irigoien et al. 2000), and may vary under different environmental conditions, grazer communities and prey suites - including those that harbor toxic phytoplankton (Teegarden et al. 2001, Colin \& Dam 2002, Kozlowsky-Suzuki et al. 2005).

The fastidiousness with which copepods feed, coupled with the ubiquity of Pseudo-nitzschia spp., both on the Washington coast and worldwide, led us to pose the hypothesis that this genus escapes intense copepod grazing. Among the candidate mechanisms that would reduce grazing mortality, an inviting hypothesis is to assume a functional role of the Pseudo-nitzschiaproduced toxin, domoic acid (DA). Compared to the suite of dinoflagellate-produced saxitoxins (e.g. Colin \& Dam 2002 and references therein) little is known about the role of DA in grazer interactions (Lincoln et al. 2001, Bargu et al. 2003, Maneiro et al. 2005).
Regardless of the cause, a refuge from grazing mortality will positively affect Pseudo-nitzschia population ecology by 3 routes: (1) directly through reduced grazing mortality, (2) by reducing competition through copepod consumption of other phytoplankton, and (3) through grazing on microzooplankton - another potential Pseudo-nitzschia grazer. To test this hypothesis, we conducted grazing experiments with the locally dominant copepod species in natural plankton assemblages along the coast of Washington State, USA. This study site is an ideal location to test this hypothesis, as physical and chemical properties, prey biomass and community composition vary greatly on short time and space scales. Clear patterns of reduced grazing on Pseudo-nitzschia under these wide-ranging prey conditions would indicate habitual grazing behaviors and, ultimately, suggest that copepod grazing influences Pseudo-nitzschia population ecology.

\section{MATERIALS AND METHODS}

Copepod grazing experiments were conducted on the Washington coast on board the RV 'Wecoma' from September 1 to 16, 2003, as part of the Pacific Northwest ECOHAB (ECOlogy of Harmful Algal Blooms) project. The sole criterion for selecting experimental stations was the presence of ample Pseudo-nitzschia cells and, because of this single constraint, experimental stations (Fig. 1) were widespread spatially, representing both onshore and offshore locations, and resulted in diverse chemical/physical conditions (Table 1) and prey communities and concentrations (see Table 2). The cross-shelf spacing of our experimental locations provided the opportunity to work with the regional dominant copepod genera Calanus, Metridia and Acartia, which represented a large size spectrum and contrasting feeding behaviors. The numerically dominant species of copepod at each location was used for experiments. Initial experimental conditions, copepod species tested and treatment replicates are shown in Table 1.

Grazing experiments. We conducted 7 copepod grazing experiments. Copepods were collected with vertical net tows using a $1 \mathrm{~m}$ diameter ring net with $200 \mu \mathrm{m}$ mesh. Vertical tows were done to a maximum depth of $200 \mathrm{~m}$, but at shallow stations to $\sim 5 \mathrm{~m}$ off the bottom. Once on deck, healthy copepods were immediately diluted into 21 polyethylene containers holding raw seawater where they were allowed to 'recover' (for $\sim 0.5 \mathrm{~h}$ ) from the net tows. Individual adult female copepods were selected under a stereomicroscope with an inverted Pasteur pipette and placed in $30 \mathrm{ml}$ beakers containing filtered seawater until the start of the experiment $(\sim 1 \mathrm{~h})$. 


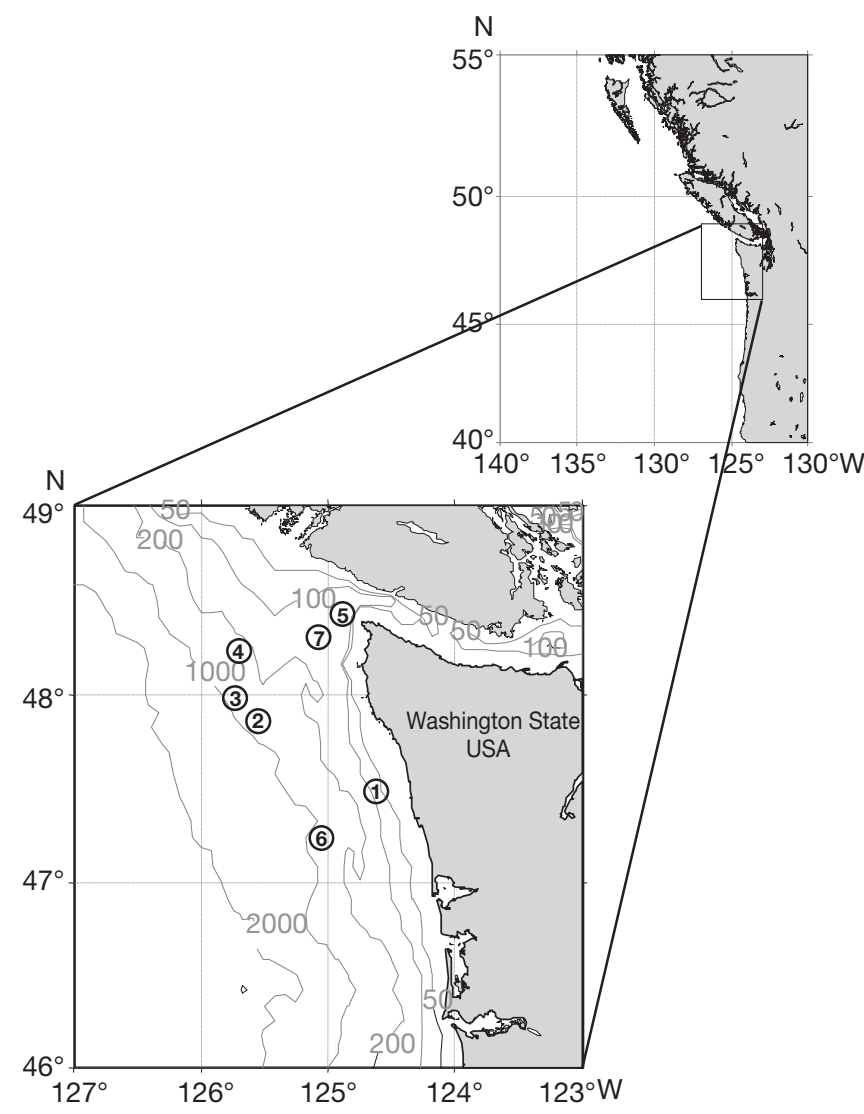

Fig. 1. Locations of Stns 1 to 7 off the coast of Washington State, USA, used for the grazing experiments. Depth contours (m) are shown

Seawater for grazing experiments (GEW) was collected from the depth of $\sim 50 \%$ surface PAR using Niskin bottles attached to a CTD rosette equipped with SeaBird environmental sensors. Once on deck, the Niskin bottles were gently drained through acid-cleaned silicone tubing (8 mm inner diameter) into acid-cleaned 501 polyethylene carboys. Undesired mesozooplankton were removed from the GEW with $200 \mu \mathrm{m}$ mesh netting attached to the silicone tubing. The plankton in the GEW were kept homogenized by slowly raising and lowering a polyethylene plunger through the water. At the same time, the well-mixed GEW was gently siphoned into 2.51 acid-cleaned polycarbonate bottles for the control and grazing experiment treatments (see Table 1 for replicate numbers). To ensure that phytoplankton growth rates were unaffected by nutrient depletion or copepod grazing-induced nutrient remineralization, we added a nutrient mixture to all bottles: $10 \mu \mathrm{M} \mathrm{NO}_{3}{ }^{-}$added as $\mathrm{NaNO}_{3}$, $10 \mu \mathrm{M} \mathrm{Si}(\mathrm{OH})_{4}$ added as $\mathrm{Na}_{2} \mathrm{O}_{3} \mathrm{Si} \cdot 9 \mathrm{H}_{2} \mathrm{O}, 0.63 \mu \mathrm{MPO}_{4}{ }^{3-}$ added as $\mathrm{NaH}_{2} \mathrm{PO}_{4} \cdot \mathrm{H}_{2} \mathrm{O}, 3 \mathrm{nM}$ Fe dissolved in $2 \% \mathrm{HCl}$ and $0.3 \mathrm{nM} \mathrm{Mn}$ added as $\mathrm{MnCl}_{2} \cdot 4 \mathrm{H}_{2} \mathrm{O}$. While filling grazing and control bottles, samples for initial size fractionated (>5 $\mu \mathrm{m}$ and $<5 \mu \mathrm{m}$ ) chlorophyll a (chl a) and microplankton counts were randomly taken in between filling experimental bottles. Separate samples for microplankton were immediately fixed in 5\% Lugol's acid or fixed within $\sim 20$ min of collection in $0.5 \%$ glutaraldehyde.

Once the grazing bottles had been filled to near capacity, the copepods were added. The number added to the experimental bottles varied with species and location (Table 1). Control and grazing bottles were placed in clear tubes covered with mylar screening to approximate in situ light levels. The tubes were secured to a revolving wheel (1 rpm) which was submerged in a Plexiglas on-deck incubator. The temperature inside the incubator was maintained by continuous flow of surface seawater.

Incubations lasted $24 \mathrm{~h}$, after which the bottles were removed from the incubator and the copepods' condition immediately assessed. Copepods appeared healthy and mortality was negligible; therefore corrections for copepod mortality were not made to final rate measurements. Samples were taken for size fractionated chl a analysis and microplankton abundances for all control and treatment bottles as per experimental set up. Net growth rates of chlorophyll size fractions and microplankton taxa, as well as copepod clearance were all calculated using the equations of Frost (1972).

Sample processing. Microplankton enumeration and biomass estimation: Aliquots from the Lugol's pre-

Table 1. Initial conditions for copepod selection experiments in 2003. Temperature, salinity and nutrient salts measured in samples from water depth that corresponded to $50 \%$ surface irradiance. Number(s) following individuals per bottle are numbers of treatment replicates

\begin{tabular}{|c|c|c|c|c|c|c|c|c|c|c|}
\hline \multirow{2}{*}{$\begin{array}{l}\text { Expt. } \\
\text { no. }\end{array}$} & \multirow{2}{*}{$\begin{array}{l}\text { Date } \\
(\mathrm{m} / \mathrm{dd})\end{array}$} & \multicolumn{2}{|c|}{ Location } & \multirow{2}{*}{$\begin{array}{l}\text { Copepod } \\
\text { species }\end{array}$} & \multirow{2}{*}{$\begin{array}{c}\text { Ind. } \\
\text { bottle }\end{array}$} & \multirow[t]{2}{*}{ Salinity } & \multirow{2}{*}{$\begin{array}{c}T \\
\left({ }^{\circ} \mathrm{C}\right)\end{array}$} & \multicolumn{3}{|c|}{ Nutrients $(\mu \mathrm{M})$} \\
\hline & & ${ }^{\circ} \mathrm{N}$ Lat & ${ }^{\circ} \mathrm{W}$ Long & & & & & $\mathrm{NO}_{3}^{-}$ & $\mathrm{PO}_{4}{ }^{3-}$ & $\mathrm{SiO}_{4}{ }^{2-}$ \\
\hline 1 & $9 / 01$ & 4731.67 & 12438.49 & Acartia longiremis & $25(3)$ & 32.8 & 10.1 & 18.3 & 1.31 & 36.6 \\
\hline 2 & $9 / 03$ & 4752.99 & 12532.02 & Metridia pacifica & $20(2)$ & 32.0 & 13.4 & 1.1 & 0.36 & 12.1 \\
\hline 3 & $9 / 06$ & 4759.03 & 12543.39 & Metridia pacifica & $50(3)$ & 31.2 & 13.9 & 4.1 & 0.50 & 26.2 \\
\hline 4 & $9 / 09$ & 4815.70 & 12540.04 & Acartia longiremis & $75(2)$ & 31.6 & 13.4 & 9.3 & 0.87 & 29.6 \\
\hline 5 & $9 / 12$ & 4826.25 & 12451.36 & Calanus pacificus & $20(2)$ & 32.5 & 11.5 & 6.2 & 0.58 & 25.5 \\
\hline 6 & $9 / 14$ & 4715.62 & 12503.70 & Metridia pacifica & $40(2)$ & 31.9 & 15.0 & 0.7 & 0.37 & 6.0 \\
\hline 7 & $9 / 16$ & 4819.36 & 12504.11 & Small assemblage & $150(4)$ & 32.2 & 11.8 & 14.1 & 1.28 & 32.0 \\
\hline
\end{tabular}


served GEW were allowed to settle for $24 \mathrm{~h}$ in either Utermöhl chambers or graduated cylinders, depending on the volume needed to accurately quantify the sample. For abundant prey taxa, several millilitres were settled directly in chambers; for the more infrequent prey taxa, larger volumes were settled in graduated cylinders for $24 \mathrm{~h}$. The following day, the top filtrate was decanted off, while the bottom $10 \mathrm{ml}$ containing the prey was resuspended and allowed to settle in a counting chamber for $24 \mathrm{~h}$ prior to counting. Slides of glutaraldehyde-fixed cells were prepared for epifluorescent microscopy according to Lessard \& Murrell (1996). Prey cells in Utermöhl chambers and glutaraldehyde-fixed slides were counted and measured with a digitizing pad, and linear dimensions were converted to biovolume according to Roff \& Hopcroft (1986). Prey biovolume was converted to cellular $\mathrm{C}$ using the equations of MendenDeuer \& Lessard (2000). Between 30 and 500 cells were counted for each prey type.

Pseudo-nitzschia spp. were separated into 2 size categories, small and large, based upon the width of the cell valve. We considered cells with a transapical axis narrower than $3 \mu \mathrm{m}$ to be small cells and part of the P. pseudodelicatisima/delicatissima/cuspidata species complex. Cells with a transapical axis wider than $3 \mu \mathrm{m}$ were considered large cells and part of the $P$. australis/fraudulenta/heimii and $P$. pungens/multiseries species complexes (Horner 2002).

Chlorophyll: Change in size-fractionated chl a over the course of the experiments was used as a proxy to determine phytoplankton community growth and grazing rates. Chlorophyll concentrations were calculated according to the acidification method of Parsons et al. (1984).

Domoic acid: Particulate DA, at or near the depth of the experimental water, was measured using the receptor binding assay (Van Dolah 1997, Trainer et al. 2002). Total particulate DA was normalized to Pseudonitzschia spp. cell biomass to give an approximate index of cellular toxicity.
Electivity indices. In order to determine the magnitude of copepod prey preference, we calculated electivity indices (Ivlev 1961). We used the selection coefficient and electivity index of Vanderploeg \& Scavia (1979a,b):

$$
W_{i}=F_{i} / \sum F_{i}
$$

where $W_{i}$ is the selection coefficient for each food type $i$, and $F_{i}$ and $\Sigma F_{i}$ are the clearance rate for food type $i$ and the sum of clearance rates for all food types, respectively. From this, the electivity index $\left(E_{i}^{*}\right)$ for all major food types within an experiment is calculated by

$$
E_{i}^{*}=\left[W_{i}-(1 / \mathrm{n})\right] /\left[W_{i}+(1 / \mathrm{n})\right]
$$

where $\mathrm{n}$ is the total number of prey types within the given experiment. This method is recommended by Lechowicz (1982) when prey abundances are unequal, and was used in a study analogous to ours by Teegarden et al. (2001). This method is convenient in that the index ranges between -1 and 1 . Neutral preference for a prey type (i.e. prey is ingested in direct proportion to its availability in the environment) is indicated by 0 , whereas positive values indicate preference and negative values indicate avoidance. The degree to which these values deviate from zero indicates the magnitude of preference.

\section{RESULTS}

\section{Initial prey biomass and composition}

Prey biomass across experiments varied by nearly 2 orders of magnitude, ranging from 34 to $1258 \mu \mathrm{g} \mathrm{C}^{-1}$ (Table 1). The highest biomass occurred at the mouth of the Juan de Fuca Strait and the lowest biomass was found off the shelf. Total phytoplankton carbon ranged

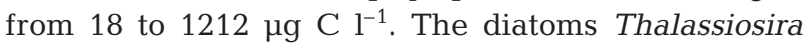
spp., and the autotrophic dinoflagellates Ceratium

Table 2. Initial chlorophyll ( $\mu$ g chlorophyll $\mathrm{l}^{-1}$ ), prey carbon concentration $\left(\mu \mathrm{g} \mathrm{C} \mathrm{l}^{-1}\right.$ ) and domoic acid concentrations in copepod selection experiments, September 2003. Ciliates include aloricate choreotrichs, holotrichs and tintinnids. H.dino: heterotrophic

\begin{tabular}{|c|c|c|c|c|c|c|c|c|c|c|c|}
\hline \multirow{3}{*}{$\begin{array}{l}\text { Expt } \\
\text { no. }\end{array}$} & \multicolumn{3}{|c|}{ — Chlorophyll $\left(\mu \mathrm{g} \mathrm{l}^{-1}\right)$ - } & \multicolumn{6}{|c|}{ - Biomass $\left(\mu \mathrm{C} \mathrm{C}^{-1}\right)$} & \multicolumn{2}{|c|}{ — Domoic acid } \\
\hline & \multirow[t]{2}{*}{$>5 \mu \mathrm{m}$} & \multirow[t]{2}{*}{$<5 \mu \mathrm{m}$} & \multirow[t]{2}{*}{ Total } & \multicolumn{3}{|c|}{ Autotrophic } & \multicolumn{3}{|c|}{ Heterotrophic } & \multirow[t]{2}{*}{$\mathrm{ng} \mathrm{l^{-1 }}$} & \multirow{2}{*}{$\begin{array}{l}\mathrm{ng} \mu \mathrm{g}^{-1} \\
\text { Pseud C }\end{array}$} \\
\hline & & & & Diatom & Other & Total & Ciliates & H.dino & Total & & \\
\hline 1 & 10.12 & 0.60 & 10.72 & 187.7 & 8.3 & 196.0 & 5.5 & 14.0 & 19.5 & 0 & 0 \\
\hline 2 & 8.89 & 0.93 & 9.82 & 47.0 & 22.6 & 69.6 & 15.3 & 10.2 & 25.5 & 40 & 11.5 \\
\hline 3 & 13.44 & 2.82 & 16.27 & 24.3 & 94.6 & 118.9 & 28.9 & 23.4 & 52.3 & 378 & 180.0 \\
\hline 4 & 3.26 & 1.77 & 5.03 & 5.6 & 45.1 & 50.7 & 16.6 & 18.1 & 34.7 & 93 & 116.3 \\
\hline 5 & 21.28 & 0.58 & 21.86 & 848.1 & 364.0 & 1212.1 & 17.8 & 28.7 & 46.5 & 56 & 13.0 \\
\hline 6 & 0.56 & 0.44 & 1.00 & 1.8 & 21.4 & 23.2 & 4.7 & 6.4 & 11.1 & 2014 & 1549.0 \\
\hline 7 & 1.46 & 1.05 & 2.52 & 9.6 & 8.8 & 18.4 & 11.0 & 7.9 & 18.9 & nd & nd \\
\hline
\end{tabular}
dinoflagellates; Pseud: Pseudo-nitzschia spp. nd: no data 
Table 3. Mean $( \pm \mathrm{SE})$ initial prey carbon and abundance estimates in experiments conducted with the natural plankton assemblage at locations off the coast of Washington State in 2003. Dates given in form $\mathrm{m} / \mathrm{dd} / \mathrm{yy}$. Number(s) following date of experiment are experimental locations (Fig. 1). Auto: autotrophic; Gymnodinoid: gymnodinoid heterotrophic dinoflagellates. -: prey negligible

\begin{tabular}{|c|c|c|c|c|c|c|c|}
\hline \multirow[t]{2}{*}{ Prey } & \multicolumn{2}{|c|}{ Acartia longiremis } & \multicolumn{3}{|c|}{ Metridia pacifica } & \multirow{2}{*}{$\begin{array}{l}\text { Calanus } \\
\text { pacificus } \\
\text { 9/11/03 (5) }\end{array}$} & \multirow{2}{*}{$\begin{array}{c}\text { Small } \\
\text { assembl. } \\
9 / 16 / 03(7)\end{array}$} \\
\hline & 8/31/03 (1) & 9/9/03 (4) & 9/3/03 (2) & 9/6/03 (3) & $9 / 14 / 03(6)$ & & \\
\hline \multicolumn{8}{|c|}{ Small Pseudo-nitzschia spp. } \\
\hline Cells ml ${ }^{-1}$ & $199.0 \pm 43.2$ & $31.4 \pm 3.7$ & $109.2 \pm 17.5$ & $68.5 \pm 6.3$ & $4.2 \pm 0.9$ & $156.4 \pm 5.3$ & $19.7 \pm 4.3$ \\
\hline$\mu \mathrm{g} \mathrm{Cl} 1^{-1}$ & $2.4 \pm 0.3$ & $0.3 \pm 0.0$ & $1.2 \pm 0.1$ & $0.6 \pm 0.1$ & $0.1 \pm 0.0$ & $1.7 \pm 0.1$ & $0.2 \pm 0.1$ \\
\hline \multicolumn{8}{|c|}{ Large Pseudo-nitzschia spp. } \\
\hline Cells ml ${ }^{-1}$ & $19.4 \pm 0.6$ & $6.6 \pm 2.6$ & $19.2 \pm 0.3$ & $15.6 \pm 0.7$ & $11.3 \pm 2.4$ & $32.0 \pm 1.4$ & $5.2 \pm 1.9$ \\
\hline$\mu \mathrm{C}^{-1}$ & $1.8 \pm 0.1$ & $0.5 \pm 0.3$ & $2.3 \pm 0.1$ & $1.5 \pm 0.2$ & $1.2 \pm 0.3$ & $2.6 \pm 0.2$ & $0.3 \pm 0.1$ \\
\hline \multicolumn{8}{|c|}{ Thalassiosira spp. } \\
\hline Cells $\mathrm{ml}^{-1}$ & $785.9 \pm 24.6$ & $5.3 \pm 0.1$ & $46.0 \pm 1.2$ & $30.6 \pm 3.1$ & - & $3708.8 \pm 70.0$ & $0.5 \pm 0.1$ \\
\hline$\mu \mathrm{g} \mathrm{C} \mathrm{l}^{-1}$ & $178.0 \pm 4.2$ & $1.5 \pm 0.1$ & $35.3 \pm 0.7$ & $19.4 \pm 4.2$ & - & $843.8 \pm 14.3$ & $0.2 \pm 0.0$ \\
\hline \multicolumn{8}{|c|}{ Chaetoceros spp } \\
\hline Cells ml ${ }^{-1}$ & $24.2 \pm 5.3$ & - & $6.2 \pm 0.4$ & - & - & - & - \\
\hline$\mu \mathrm{g} \mathrm{C} 1^{-1}$ & $2.2 \pm 0.3$ & - & $0.7 \pm 0.1$ & - & - & - & - \\
\hline \multicolumn{8}{|l|}{ Corethron spp. } \\
\hline Cells $\mathrm{ml}^{-1}$ & - & _- & - & - & _- & - & $0.5 \pm 0.1$ \\
\hline$\mu \mathrm{gCl}^{-1}$ & - & - & - & - & - & - & $0.4 \pm 0.0$ \\
\hline \multicolumn{8}{|c|}{ Coscinodiscus spp. } \\
\hline Cells ml $\mathrm{m}^{-1}$ & - & $0.7 \pm 0.2$ & - & - & - & - & $0.8 \pm 0.1$ \\
\hline$\mu \mathrm{g} \mathrm{Cl}^{-1}$ & - & $3.2 \pm 0.1$ & - & - & - & - & $8.4 \pm 0.8$ \\
\hline \multicolumn{8}{|c|}{ Guinardia spp. } \\
\hline Cells ml ${ }^{-1}$ & $12.7 \pm 2.0$ & $0.6 \pm 0.1$ & $1.4 \pm 0.8$ & $8.8 \pm 1.7$ & - & - & - \\
\hline$\mu \mathrm{g} \mathrm{Cl}^{-1}$ & $2.5 \pm 0.6$ & $0.2 \pm 0.1$ & $0.7 \pm 0.4$ & $2.8 \pm 0.5$ & - & - & - \\
\hline \multicolumn{8}{|c|}{ Leptocylindrus spp. } \\
\hline Cells ml ${ }^{-1}$ & $27.9 \pm 4.4$ & - & - & - & - & - & - \\
\hline$\mu \mathrm{g} \mathrm{C} 1^{-1}$ & $0.9 \pm 0.2$ & - & - & - & - & - & - \\
\hline \multicolumn{8}{|l|}{ Dictyocha spp. } \\
\hline Cells ml ${ }^{-1}$ & - & $0.2 \pm 0.0$ & - & - & - & - & $0.6 \pm 0.1$ \\
\hline$\mu \mathrm{g} \mathrm{Cl}^{-1}$ & - & $0.0 \pm 0.0$ & - & - & - & - & $0.2 \pm 0.0$ \\
\hline Ceratium spp. & & & & & & & \\
\hline Cells ml ${ }^{-1}$ & $0.2 \pm 0.0$ & $2.8 \pm 0.0$ & $2.5 \pm 0.1$ & $7.9 \pm 1.7$ & $5.2 \pm 0.6$ & $26.4 \pm 2.5$ & $0.3 \pm 0.1$ \\
\hline$\mu \mathrm{g} \mathrm{Cl}^{-1}$ & $1.6 \pm 0.3$ & $17.3 \pm 0.9$ & $17.5 \pm 0.4$ & $52.2 \pm 12.2$ & $19.3 \pm 0.6$ & $330.0 \pm 37.1$ & $1.4 \pm 0.5$ \\
\hline Prorocentrum & & & & & & & \\
\hline Cells ml ${ }^{-1}$ & $1.7 \pm 0.2$ & $40.6 \pm 0.6$ & $3.5 \pm 0.1$ & $60.2 \pm 5.7$ & $0.4 \pm 0.0$ & $39.4 \pm 1.1$ & $7.6 \pm 0.0$ \\
\hline$\mu g \mathrm{Cl}^{-1}$ & $1.5 \pm 0.3$ & $19.3 \pm 0.2$ & $2.7 \pm 0.1$ & $29.8 \pm 5.0$ & $0.3 \pm 0.0$ & $24.7 \pm 1.1$ & $4.4 \pm 0.6$ \\
\hline Auto dinoflag & $<20 \mu \mathrm{m}$ & & & & & & \\
\hline Cells ml ${ }^{-1}$ & $24.4 \pm 1.9$ & $80.6 \pm 22.0$ & $19.1 \pm 1.9$ & $110.0 \pm 12.5$ & $22.5 \pm 2.0$ & $90.0 \pm 6.4$ & $31.2 \pm 1.8$ \\
\hline$\mu \mathrm{g} \mathrm{C} 1^{-1}$ & $3.5 \pm 0.0$ & $6.7 \pm 0.0$ & $1.57 \pm 0.6$ & $9.5 \pm 3.0$ & $1.6 \pm 0.2$ & $7.8 \pm 1.8$ & $2.7 \pm 0.1$ \\
\hline Cryptophytes & & & & & & & \\
\hline Cells ml ${ }^{-1}$ & $33.7 \pm 2.5$ & $55.3 \pm 23.4$ & $15.0 \pm 1.5$ & $77.5 \pm 17.5$ & $7.2 \pm 0.2$ & $44.0 \pm 1.1$ & $12.9 \pm 0.3$ \\
\hline$\mu \mathrm{g} \mathrm{Cl}^{-1}$ & $1.7 \pm 0.0$ & $1.8 \pm 1.0$ & $0.8 \pm 0.3$ & $3.1 \pm 0.4$ & $0.2 \pm 0.0$ & $1.5 \pm 0.1$ & $0.3 \pm 0.1$ \\
\hline Tintinnids & & & & & & & \\
\hline Cells ml ${ }^{-1}$ & $0.1 \pm 0.0$ & $1.1 \pm 0.1$ & $1.1 \pm 0.2$ & $1.7 \pm 0.0$ & - & $4.7 \pm 0.3$ & $1.0 \pm 0.1$ \\
\hline$\mu \mathrm{g} \mathrm{Cl}^{-1}$ & $0.1 \pm 0.0$ & $0.6 \pm 0.3$ & $0.4 \pm 0.1$ & $0.8 \pm 0.3$ & - & $1.4 \pm 0.2$ & $0.2 \pm 0.0$ \\
\hline Ciliates $>40 \mu$ & & & & & & & \\
\hline Cells $\mathrm{ml}^{-1}$ & $0.6 \pm 0.0$ & $1.7 \pm 0.1$ & $4.2 \pm 0.1$ & $4.2 \pm 0.2$ & $0.4 \pm 0.6$ & $2.5 \pm 0.3$ & $1.3 \pm 0.0$ \\
\hline$\mu g \mathrm{Cl}^{-1}$ & $2.5 \pm 0.1$ & $8.4 \pm 0.6$ & $12.4 \pm 0.1$ & $18.7 \pm 1.5$ & $1.3 \pm 0.2$ & $12.0 \pm 2.4$ & $3.1 \pm 0.3$ \\
\hline Ciliates $20-40$ & & & & & & & \\
\hline Cells ml ${ }^{-1}$ & $1.7 \pm 0.0$ & $1.4 \pm 0.1$ & $1.5 \pm 0.5$ & $2.4 \pm 0.1$ & $0.7 \pm 0.2$ & $2.4 \pm 0.1$ & $2.9 \pm 0.7$ \\
\hline$\mu \mathrm{g} \mathrm{C} \mathrm{l}^{-1}$ & $2.2 \pm 0.1$ & $2.6 \pm 0.1$ & $1.6 \pm 0.5$ & $4.3 \pm 1.1$ & $0.8 \pm 0.2$ & $3.6 \pm 0.4$ & $3.9 \pm 1.9$ \\
\hline Ciliates $<20 \mu$ & & & & & & & \\
\hline Cells $\mathrm{ml}^{-1}$ & $3.1 \pm 0.5$ & $19.4 \pm 2.8$ & $2.7 \pm 0.3$ & $19.4 \pm 0.2$ & $10.0 \pm 3.8$ & $1.9 \pm 0.4$ & $16.6 \pm 2.8$ \\
\hline$\mu g \mathrm{Cl}^{-1}$ & $0.7 \pm 0.1$ & $5.0 \pm 0.4$ & $0.9 \pm 0.1$ & $5.1 \pm 0.5$ & $2.6 \pm 0.9$ & $0.8 \pm 0.2$ & $3.8 \pm 0.5$ \\
\hline Protoperidiniz & & & & & & & \\
\hline Cells ml ${ }^{-1}$ & $0.3 \pm 0.0$ & $0.5 \pm 0.1$ & $0.4 \pm 0.0$ & $0.6 \pm 0.1$ & $0.3 \pm 0.0$ & $1.0 \pm 0.2$ & $0.3 \pm 0.0$ \\
\hline$\mu \mathrm{g} \mathrm{C} \mathrm{l}^{-1}$ & $1.7 \pm 0.5$ & $3.1 \pm 1.8$ & $2.0 \pm 0.5$ & $3.7 \pm 0.4$ & $2.9 \pm 0.5$ & $5.5 \pm 1.6$ & $0.9 \pm 0.1$ \\
\hline Gymnodinoid & & & & & & & \\
\hline Cells ml ${ }^{-1}$ & $0.3 \pm 0.0$ & $1.9 \pm 0.1$ & $0.6 \pm 0.0$ & $1.8 \pm 0.6$ & $0.9 \pm 0.0$ & $3.3 \pm 0.3$ & $0.8 \pm 0.2$ \\
\hline$\mu \mathrm{g} \mathrm{Cl} 1^{-1}$ & $0.4 \pm 0.0$ & $3.9 \pm 0.0$ & $1.4 \pm 0.0$ & $3.6 \pm 0.7$ & $0.9 \pm 0.0$ & $8.5 \pm 1.1$ & $1.0 \pm 0.3$ \\
\hline Gymnodinoid & & & & & & & \\
\hline Cells ml ${ }^{-1}$ & $92.5 \pm 5.0$ & $99.3 \pm 23.4$ & $46.1 \pm 0.4$ & $113.7 \pm 1.3$ & $25.2 \pm 0.8$ & $105.0 \pm 6.4$ & $43.4 \pm 1.5$ \\
\hline$\mu \mathrm{C} \mathrm{Cl}^{-1}$ & $11.9 \pm 1.2$ & $11.1 \pm 2.0$ & $6.8 \pm 0.1$ & $16.1 \pm 7.0$ & $2.6 \pm 0.2$ & $14.7 \pm 0.4$ & $6.0 \pm 0.2$ \\
\hline
\end{tabular}


spp., Prorocentrum spp. contributed most to total biomass (Table 3). Pseudo-nitzschia spp. never contributed greatly to total biomass, but still comprised an appreciable portion of the prey suite, as represented by their cellular abundance (Table 3). Cyanobacteria and other picoeukaryotes were abundant at all sites, but because they are inefficiently grazed by calanoid copepods (Nival \& Nival 1976), they were not included in the available prey suite. Total heterotrophic biomass

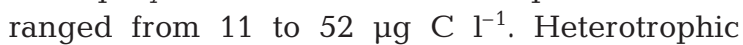
dinoflagellates contributed most to microzooplankton biomass in 4 of the 7 experiments and contributed most to cell numbers in all experiments. Biomass differences between heterotrophic dinoflagellates and ciliates were not statistically different (paired $t$-test, $\mathrm{p}>>0.05$ ); however, because of the low sample size, statistical power was weak. The most dominant microzooplankton in both biomass and cell concentration were naked gymnodinoid dinoflagellates $<40 \mu \mathrm{m}$ in length of the longest axis. The larger heterotrophic dinoflagellates Gyrodinium cf. spirale and Protoperidinium spp. were present in all cases with appreciable biomass, especially during Expts 3, 4 and 5 (Table 3). Aloricate choreotrich ciliate cell concentration and biomass was substantial. Ciliate cell numbers were dominated by cells $<20 \mu \mathrm{m}$ in length and, in general, biomass varied evenly amongst experiments; 2 exceptions were Expts 3 and 5, in which biomass of ciliates $>40 \mu \mathrm{m}$ in

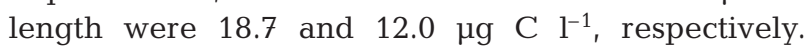
Holotrich ciliates were extremely rare and, with 1 exception (Expt 5), tintinnid ciliates were sparse.

\section{Copepod clearance rates and selectivity on prey taxa}

No consistent pattern of copepod clearance was seen for any given prey species, including Pseudo-nitzschia, across all experiments (Figs. 2 to 5). Acartia longiremis cleared small and large Pseudo-nitzschia spp. cells at high rates in Expt 1, both in terms of total clearance and relative to other prey types. In Expt 4, A. longiremis total clearance was low for the entire prey suite, with Pseudo-nitzschia being cleared at rates equivalent to those for other prey (Fig. 2B). The highest clearance rates by $A$. longiremis in Expt 1 were on autotrophic prey, but were low for the biomass dominant Thalassiosira spp., which represented $83 \%$ of available prey. In Expt 4, A. longiremis cleared ciliates, specifically tinitinnid ciliates, and heterotrophic dinoflagellates at high rates. As in Expt 1, the biomass dominants Ceratium divaricatum and Prorocentrum spp. were cleared at the lowest rates.

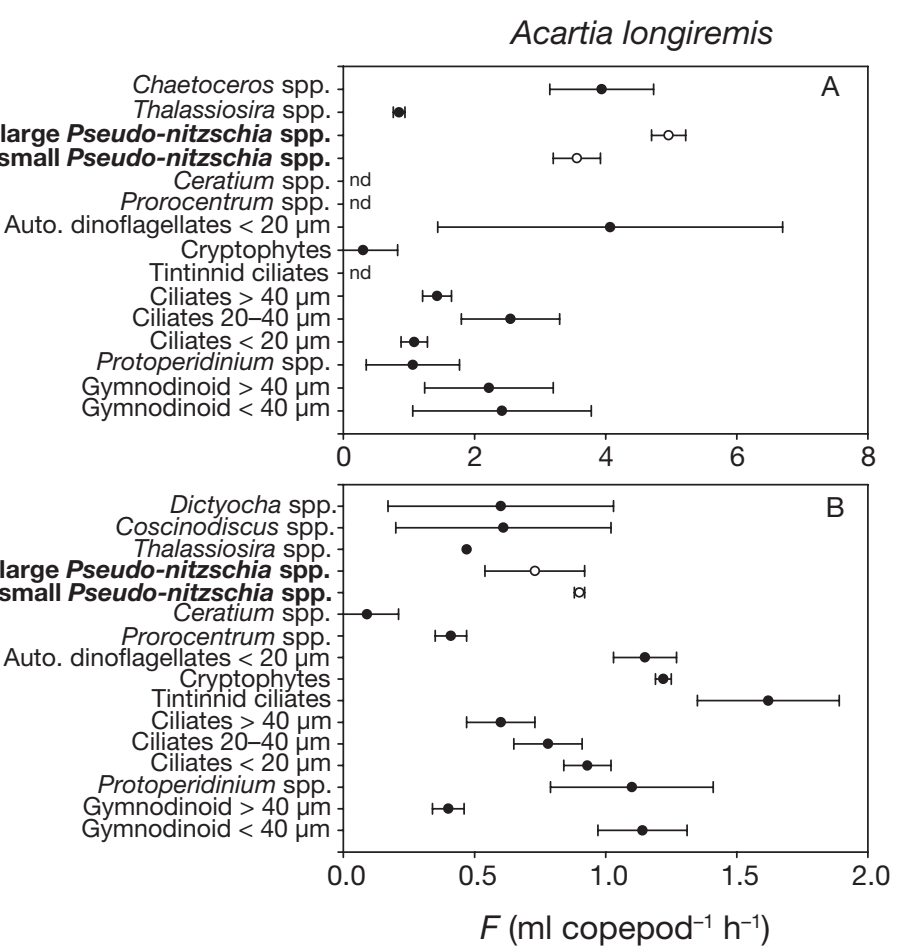

Fig. 2. Acartia longiremis. Mean $\pm \mathrm{SE}$ clearance (i.e. filtering, $F$ ) rates on natural prey assemblages in (A) Expt 1 and (B) Expt 4. Pseudonitzschia spp. denoted by open symbols for clarity. nd: negative rate calculated; Gymnodinoid: gyrodinium and gymnodinium-like dino-

flagellates; Auto.: autotrophic. Note different scales of abscissas

Metridia pacifica cleared Pseudo-nitzschia spp. at low absolute and comparative rates in 2 of the 3 experiments illustrated (Fig. 3B,C). The highest rates of Pseudo-nitzschia clearance by $M$. pacifica was during Expt 2, which was coincident with the highest Pseudonitzschia biomass of the 3 experiments. M. pacifica cleared microzooplankton, especially large dinoflagellates and ciliates $(>40 \mu \mathrm{m})$, at high rates in all experiments. As with Acartia longiremis, M. pacifica clearance rates of the biomass dominants was low. The exception to this was Expt 6, in which $M$. pacifica cleared Ceratium furca and $C$. lineatum (representing $57 \%$ of total prey biomass) at high rates (Fig. 3C).

Calanus pacificus cleared both small and large Pseudo-nitzschia spp. at $\sim 2 \mathrm{ml}$ copepod ${ }^{-1} \mathrm{~h}^{-1}$, but these rates were low compared to those for the rest of the prey suite (Fig. 4). With the exception of autotrophic dinoflagellates $<20 \mu \mathrm{m}$ in diameter, only microzooplankton were cleared at rates higher than $3 \mathrm{ml}$ cope$\operatorname{pod}^{-1} \mathrm{~h}^{-1}$. The highest clearance rates were on gymnodinoid dinoflagellates, including Gyrodinium cf. spirale (max. $>8 \mathrm{ml} \mathrm{copepod}^{-1} \mathrm{~h}^{-1}$ ). The high clearance rates on microzooplankton are surprising given that of $1258 \mu \mathrm{g} \mathrm{C} \mathrm{l}^{-1}$, only $48 \mu \mathrm{g} \mathrm{C} \mathrm{l^{-1 }}$ were represented by these heterotrophic prey. 




Fig. 3. Metridia pacifica. Mean \pm SE clearance rates in (A) Expt 2, (B) Expt 3 and (C) Expt 6. Further details as in Fig. 2. Note different scales of abscissas

Of the 3 species of calanoid copepods, Metridia pacifica appears to be the most selective feeder. The mean absolute $E_{i}{ }^{*}$ value for the $3 \mathrm{M}$. pacifica experiments was 0.36, whereas for Acartia longiremis, Calanus pacificus and the small community, $E_{i}^{*}$ values were $0.27,0.28$ and 0.31 , respectively. M. pacifica showed a particularly high affinity for heterotrophic gymnodinoid dinoflagellates and ciliates $>40 \mu \mathrm{m}$, with $E_{i}{ }^{*}$ values $\sim 0.5$ for both prey types in 2 of the 3 experiments illustrated (Fig. 7).

Calanus pacificus showed strong selection against the 2 large autotrophic dinoflagellates, Ceratium spp. and Prorocentrum spp., and for all diatoms present in the prey suite, including Pseudo-nitzschia spp. (Fig. 8). Positive selection was seen only for dinoflagellates and ciliates.

The small copepod community assemblage showed substantial selectivity (Fig. 9). The highest level of negative selection was seen on the large autotrophic dinoflagellates Ceratium spp. and on the silicoflagellates Dictyocha spp. Both large and small Pseudo-nitzschia spp. were also strongly selected against. Highest positive selection was seen on Thalassiosira spp., ciliates of 20 to $40 \mu \mathrm{m}$ and heterotrophic dinoflagellates $<40 \mu \mathrm{m}$.

\section{DISCUSSION}

Copepods generally selected against or had no preference for Pseudo-nitzschia spp. The sole exception was Acartia longiremis, which showed positive selection for Pseudonitzschia (perhaps slightly more for the larger cells) during Expt 1 (Fig. 6A). Acartia

The small copepod assemblage cleared all prey types at extremely low rates, but especially for Pseudonitzschia spp., Ceratium spp. and Dictyocha spp. (Fig. 5). The highest clearance rates for this mixed copepod assemblage was on Thalassiosira spp., heterotrophic gymnodinoid dinoflagellates and ciliates $<40 \mu \mathrm{m}$, and cryptophytes.

The electivity indices confirm the trends seen in the clearance rates. For Acartia longiremis, the $E_{i}^{*}$ for both size classes of Pseudo-nitzschia spp. in Expt 1 were positively selected for, whereas in Expt $4, E_{i}^{*}$ was essentially zero, indicating no preference for Pseudonitzschia (Fig. 6). In both A. longiremis experiments prey biomass dominants were selected against. This was most evident in Expt 4 on the prey type Ceratium spp. spp. are known to switch feeding modes between suspension feeding and ambush feeding (Kiørboe et al. 1996). The switch is an apparent attempt by the copepod to maximize energy intake rates, and may depend on the motile behavior of the most abundant prey types. For example, low abundance of non-motile prey (e.g. diatoms) and high abundance of motile prey (e.g. dinoflagellates) would induce a change from filter feeding to ambush feeding. In Expt 1, diatoms dominated prey biomass (85\%), with Thalassiosira spp. representing $83 \%$ of the total biomass. It is likely that in this experiment $A$. longiremis was feeding by filtration and, consequently, the non-motile Pseudo-nitzschia were ingested at rates higher than those for motile prey. In contrast, motile prey, most specifically dinofla- 


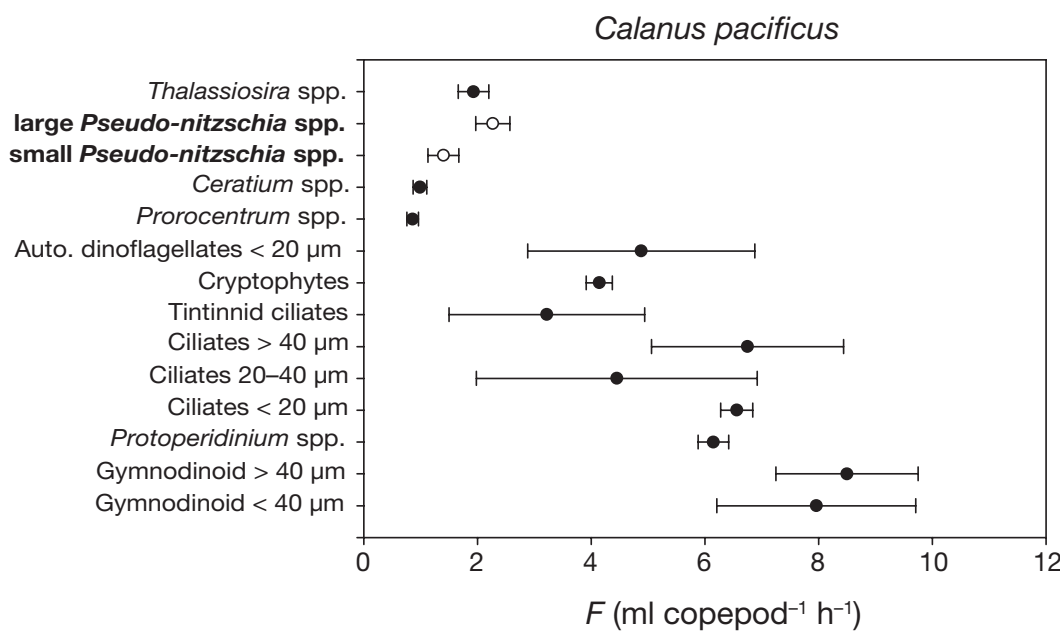

Fig. 4.Calanus pacificus. Mean \pm SE clearance rates in Expt 5. Further details as in Fig. 2

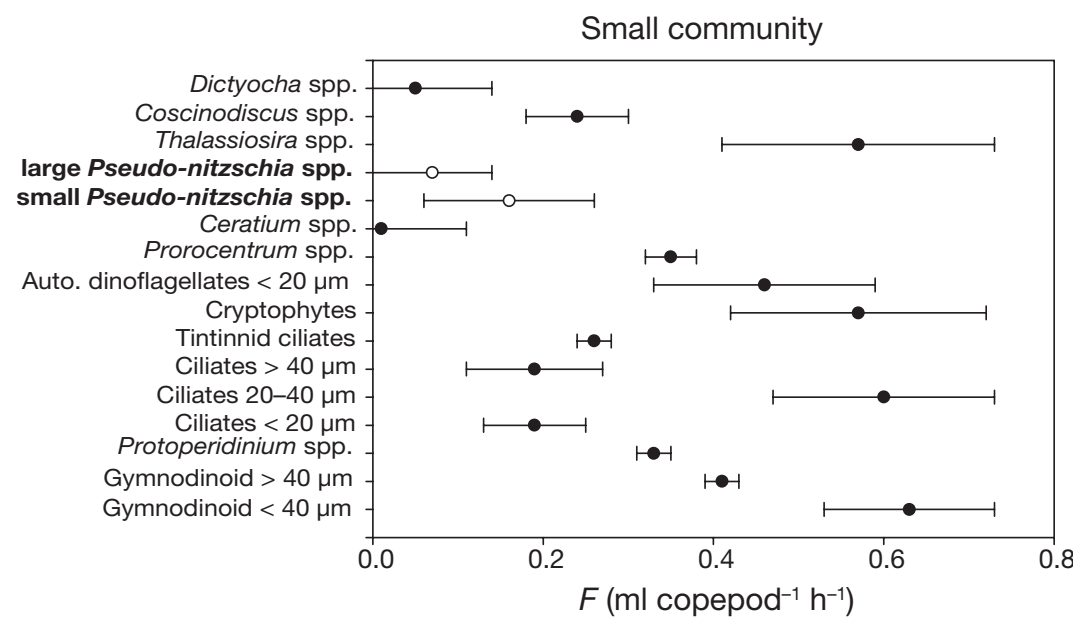

Fig. 5. Small copepod community assemblage. Mean \pm SE clearance rates in Expt 7. Further details as in Fig. 2

gellates and ciliates, were the dominant biomass in Expt 4. In this experiment clearance rates were low; Pseudo-nitzschia appeared to be neutrally selected while other diatoms were negatively selected (Fig. 6B).

The fact that Pseudo-nitzschia spp. were generally not a preferred prey type is likely to be a consequence of the rich diversity of the prey assemblages in our study, rather than the toxicity of Pseudo-nitzschia cells. Several lines of reasoning support this conclusion. First, although strong positive selection for Pseudo-nitzschia by Acartia longiremis was observed in the single experiment (Expt 7) in which DA was undetectable (Table 2), the data do not show a consistent trend of stronger negative selection towards the most toxic cells. Moreover, most negative preference indices towards Pseudonitzschia were within (and usually much less than) the range for non-toxic prey types. Second, other studies
(Lincoln et al. 2001, Maneiro et al. 2005) have found calanoid copepod feeding rates and selectivity to be the same between toxic and non-toxic Pseudonitzschia. Third, it is likely that in order for the copepods to achieve the required balanced diet, selection towards non-diatom prey is essential when diatoms dominate the prey suite (Jones \& Flynn 2005). In our experiments, diatom biomass was consistently substantial and, in 2 experiments, quite high. Therefore, Pseudo-nitzschia spp. may have been avoided because they are diatoms.

Perhaps another candidate mechanism that prevents Pseudo-nitzschia spp. from being selected is their needlelike shape and propensity to form chains. Due to the higher abundance of small Pseudo-nitzschia cells, on a per cell basis a copepod is more likely to encounter a small rather than a large Pseudo-nitzschia cell. Based upon our average per cell biomass estimates (data not shown), the ingestion of $\sim 19$ small Pseudo-nitzschia cells would be required to equal the ingested carbon from one Thalassiosra spp. cell. Assuming a copepod were to encounter a large Pseudo-nitzschia cell, then 2.6 Pseudonitzschia spp. cells would be required to achieve the equivalent carbon content of one Thalassiosra spp. cell. From an energetic standpoint it makes little sense for a copepod to select for Pseudo-nitzschia, which are frequently in long chains and would require significant handling time, over other equally abundant prey types.

The overall low clearance rates on Pseudo-nitzschia spp. imply that the adult copepod community has little direct effect on their population ecology. To estimate this, we used the equation

$$
\mathrm{PPC}=\left(I R_{\mathrm{C}} \cdot N\right) /(G M \cdot \mu)
$$

where PPC is the percent of Pseudo-nitzschia spp. production consumed, $I R_{\mathrm{c}}$ is the ingestion rate copepod ${ }^{-1}$ in a given experiment, $N$ is the estimated copepod population size, GM is the geometric mean population size of Pseudo-nitzschia, and $\mu$ is the intrinsic rate of Pseudo-nitzschia growth estimated from concurrent dilution experiments (Olson et al. unpubl.). Using published estimates of copepod abundance on the Washington and Oregon coasts (Postel et al. 1980, 1982, Morgan et al. 2003) and our clearance rate measurements, we calculated the potential impact by the adult 


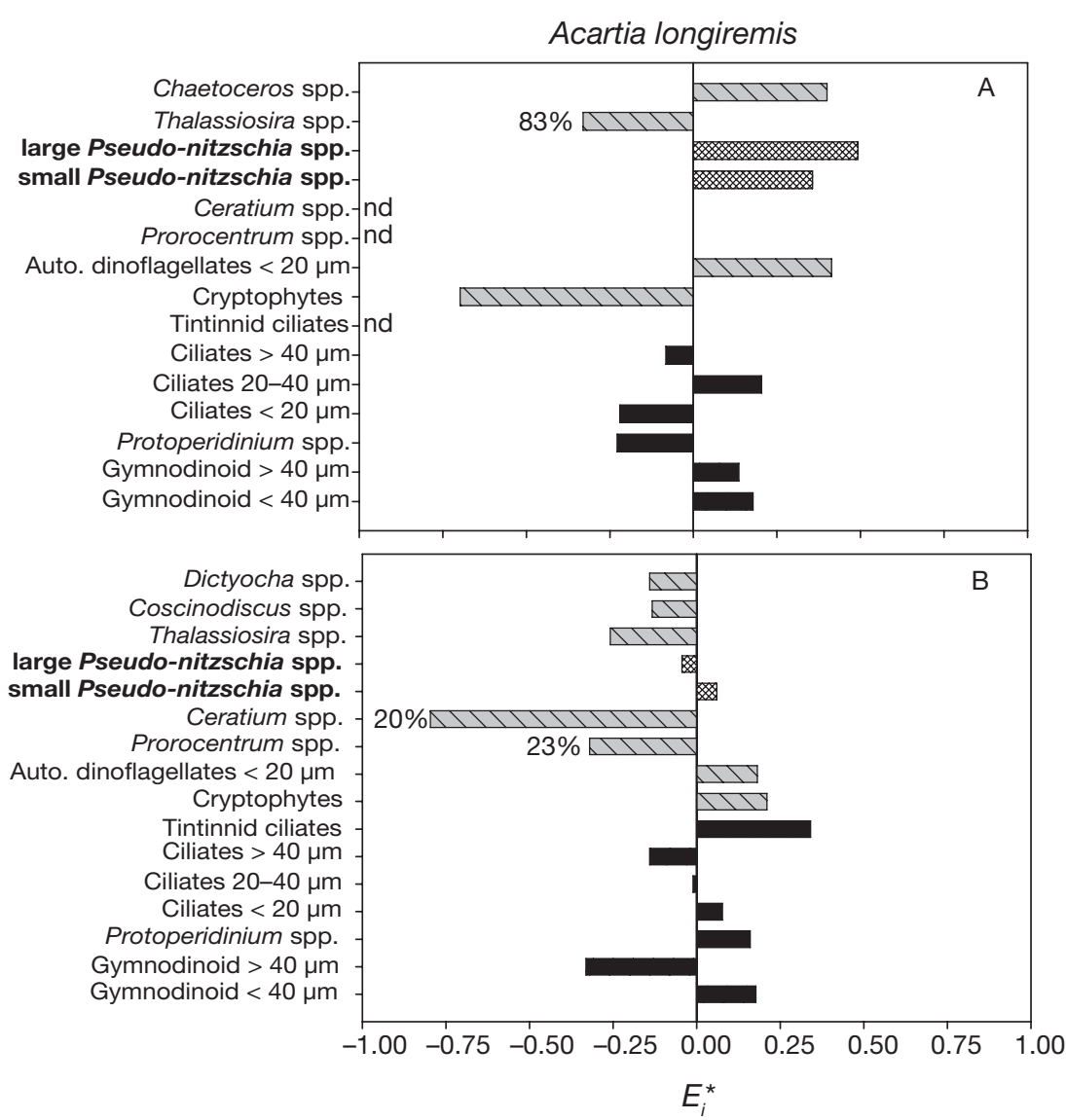

Fig. 6. Acartia longiremis. Electivity indices $\left(E_{i}^{*}\right)$ for copepods feeding on natural prey assemblages in (A) Expt 1 and (B) Expt 4. Cross-hatched bars: Pseudonitzschia spp.; hatched bars: diatoms and all other autrophs; black bars: heterotrophs. Percent contribution to total biomass of biomass dominants in each experiment is shown. nd: prey types whose $E_{i}{ }^{*}$ were incalculable due to negative clearance estimates; Gymnodinoid: gyrodinium and gymnodinium-like dinoflagellates; Auto.: autotrophic

copepod community on Pseudo-nitzschia production. Using mean copepod abundance values, the grazing impact on Pseudo-nitzschia production varied amongst the copepod species but was always minimal (Table 4). Due to their higher abundance, Acartia longiremis and the small copepod community have the greatest potential to impact Pseudo-nitzschia populations. However, at mean typical copepod concentrations, we calculated a consumption of only 7 and 10\% Pseudo-nitzschia production by the $A$. longiremis and small copepod community. If, however, the maximum values of copepod abundance were to co-occur with a Pseudonitzschia population growing at rates equal to those seen in this study, the potential impact on Pseudonitzschia production would be significant, but, again, only for A. longiremis and the small copepod community.

Perhaps the most discernible and interesting trend we found was the negative selection towards the prey types whose biomass contributed most to total biomass in each experiment. In nearly all of our experiments, the biomass dominant prey types were the diatoms Thalassiosira spp. and the autotrophic dinoflagellates Ceratium spp. and Prorocentrum spp. The only exception was Expt 7, in which the diatoms Coscinodiscus spp. and heterotrophic gymnodinoid dinoflagellates $<40 \mu \mathrm{m}$ dominated prey biomass. With regard to the avoidance of Thalassiosira spp., among the many possible explanations are poor nutritional quality (Jones \& Flynn 2005), morphological defenses (Hamm et al. 2003) and (perhaps most likely) toxic aldehyde production (e.g. Miralto et al. 1999). In an enclosed region of the Puget Sound geographically very near to our study site, Leising et al. (2005) also found that the dominant diatoms (usually Thalassiosira spp.) were avoided. Their study reported lower copepod naupliar survival when the prey field was limited to Thalassiosira spp. diatoms, which were subsequently isolated and shown to produce high levels of aldehydes (Wichard et al. 2005). Leising et al. (2005) further found that when other prey were abundant in later weeks, these same Thalassiosira spp. diatoms were avoided. Although we did not measure diatom aldehyde production and naupliar survival, these same Thalassiosira spp. were present in our experiments; by extension, it is plausible that the copepods in our experiments were avoiding Thalassiosira spp. for similar reasons.

It is less obvious why the copepods tested in our study avoided the autotrophic dinoflagellates Ceratium spp. (mostly C. divaricatum) and Prorocentrum spp., especially since the latter has been used as staple food for copepods (Rey-Rassat et al. 2002). One explanation could be size selection; Ceratium spp. are generally considered too large to be effectively grazed by many copepod species (Nielsen 1991, Granéli et al. 1993). In Expts 2, 3 and 6, Ceratium spp. dominated the prey biomass with contributions of 20,30 and $57 \%$, respectively. In Expts 2 and 3, C. divaricatum, with an average biovolume of $3.43 \times 10^{4} \mu^{-3}$, had negative $E_{i}^{*}$ values of -0.72 and -0.38 , respectively. During Expt 6, C. divaricatum was replaced in dominance by $C$. lineatum, with an average biovolume one-third $(1.27 \times$

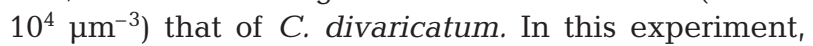
C. lineatum contributed $57 \%$ to total prey biomass and 


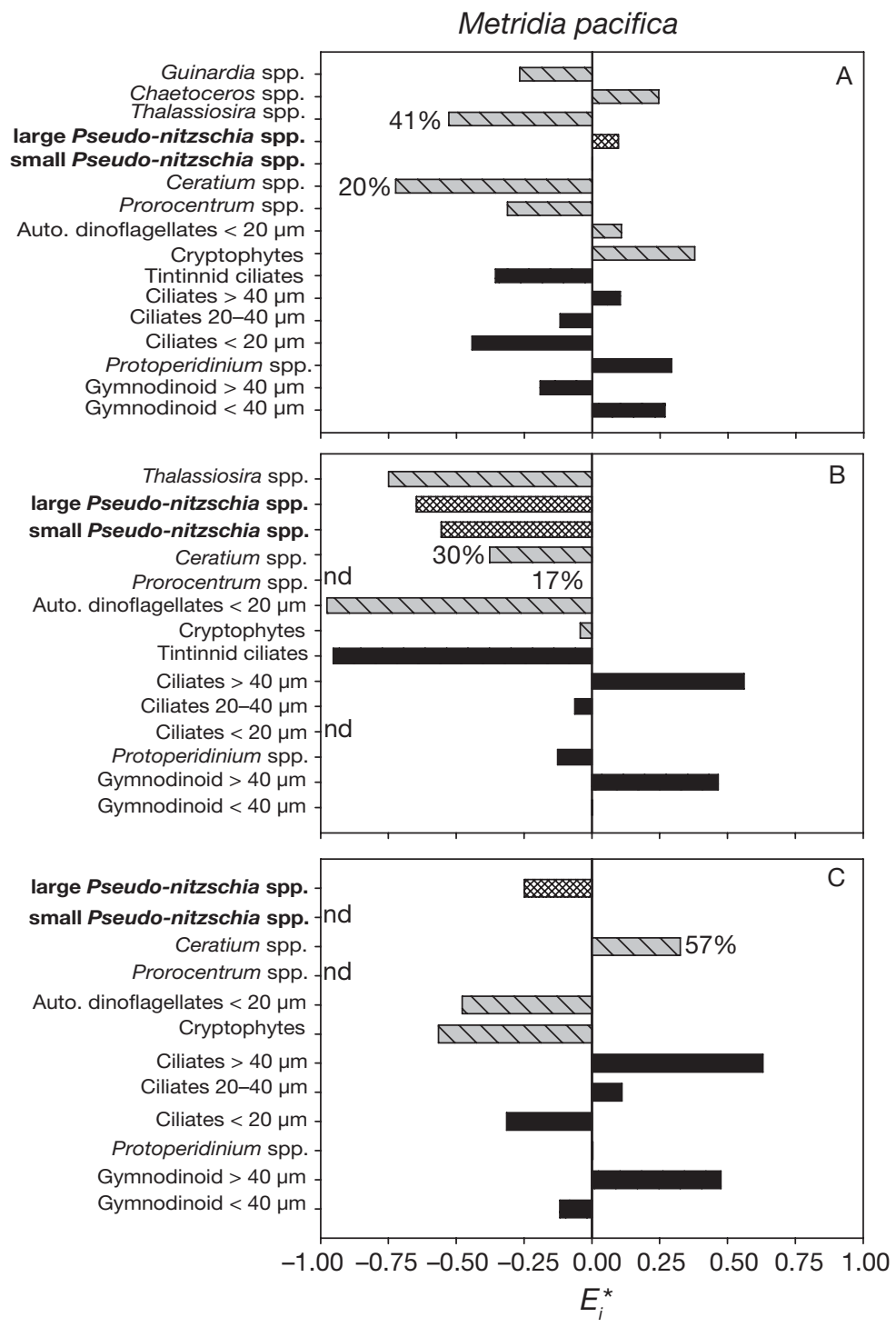

Fig. 7. Metridia pacifica. Electivity indices $\left(E_{i}^{*}\right)$ for copepods feeding on natural prey assemblages in (A) Expt 2, (B) Expt 3 and (C) Expt 6. Further details as in Fig. 6

had an $E_{i}^{*}$ of 0.33 , indicating considerable preference. In 6 of the 7 experiments Ceratium spp. and Prorocentrum spp. dinoflagellates were either not ingested or highly selected against. These large autotrophic dinoflagellates grow relatively slowly; consequently, their accumulation in the plankton must be partly the result of lower predation.

The results of our study agree with those of many other studies showing that heterotrophic protists are an important (e.g. Fessenden \& Cowles 1994, Calbet \& Saiz 2005), if not preferred (Wiadnyana \& Rassoulzadegan 1989, Leising et al. 2005), component of a copepod's diet. In every experiment, we found that microzooplankton were cleared at high rates and were highly preferred based on $E_{i}{ }^{*}$ values, even at locations where autotrophic biomass was much greater than heterotrophic biomass. The most striking example was Expt 5 with Calanus pacificus. In this experiment, microzooplankton contributed only $4 \%$ out of a possible $1259 \mu \mathrm{g} \mathrm{Cl}^{-1}$ of prey carbon, yet were cleared at rates $8 \times$ higher than those of the most abundant phytoplankters, Thalassiosira spp. and Ceratium divaricatum. These results agree with those of Leising et al. (2005) who found that C. pacificus cleared microzooplankton preferentially and at high rates, even when diatom biomass far exceeded that of microzooplankton.

In addition to aldehydes being a reasonable hypothesis as to why copepods would select for non-diatom prey, the need for copepods to achieve a balanced diet may also play a role (Jones \& Flynn 2005). Klein Breteler et al. (1999) showed that 2 copepod species, Temora longicornis and Pseudocalanus elongatus, were unable to survive on a diet of the phytoplankton Dunaliella sp. However, when these same copepods grazed on the heterotrophic dinoflagellate Oxyrrhis marina, which had been grown on Dunaliella sp., they rapidly matured from nauplii to adult. These authors hypothesized that, by way of their high unsaturated fatty acid and sterol content, heterotrophic protists not only transfer energy and cellular constituents from lower trophic levels, but also 'upgrade' the food the copepod receives with their own cellular additions. The nutritional benefit achieved by a copepod grazing on microzooplankton, however, may be species- or essential fatty acid-specific (Broglio et al. 2003); in monospecific experiments, Ederington et al. (1995) and Klein Breteler et al. (2004) found no nutritional benefit to copepods grazing on 2 ciliate species compared to algal diets. Nonetheless, by increasing the prey fatty acid spectrum, selective grazing on microzooplankton may be nutritionally advantageous for copepods. This being so, reasonable questions are: 'How does this intense grazing pressure on microzooplankton affect productive, coastal ecosystems?' and, 'Can the population ecology of Pseudo-nitzschia spp. and the other dominant phytoplankton encountered in this study be positively impacted by copepod predation on microzooplankton?'

In our experiments, selective grazing behavior of copepods on microzooplankton clearly impacted the $<5 \mu \mathrm{m}$ chlorophyll size fraction (Fig. 10), as evidenced by the significant increase in $<5 \mu \mathrm{m}$ chl a net growth rate when copepods were present. This is evidence of a 'trophic cascade,' whereby the grazing mortality of ciliates and smaller $(\leq 30 \mu \mathrm{m})$ heterotrophic dinoflagellates releases 


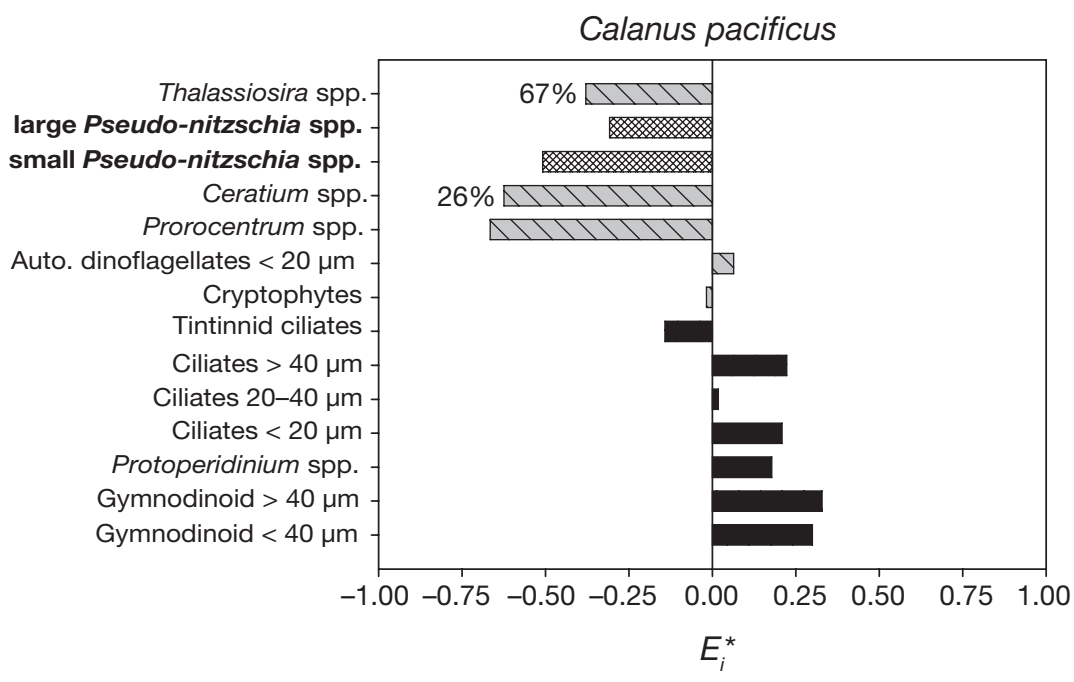

Fig. 8. Calanus pacificus. Electivity indices $\left(E_{i}^{*}\right)$ for copepods feeding on natural prey assemblages in Expt 5. Further details as in Fig. 6

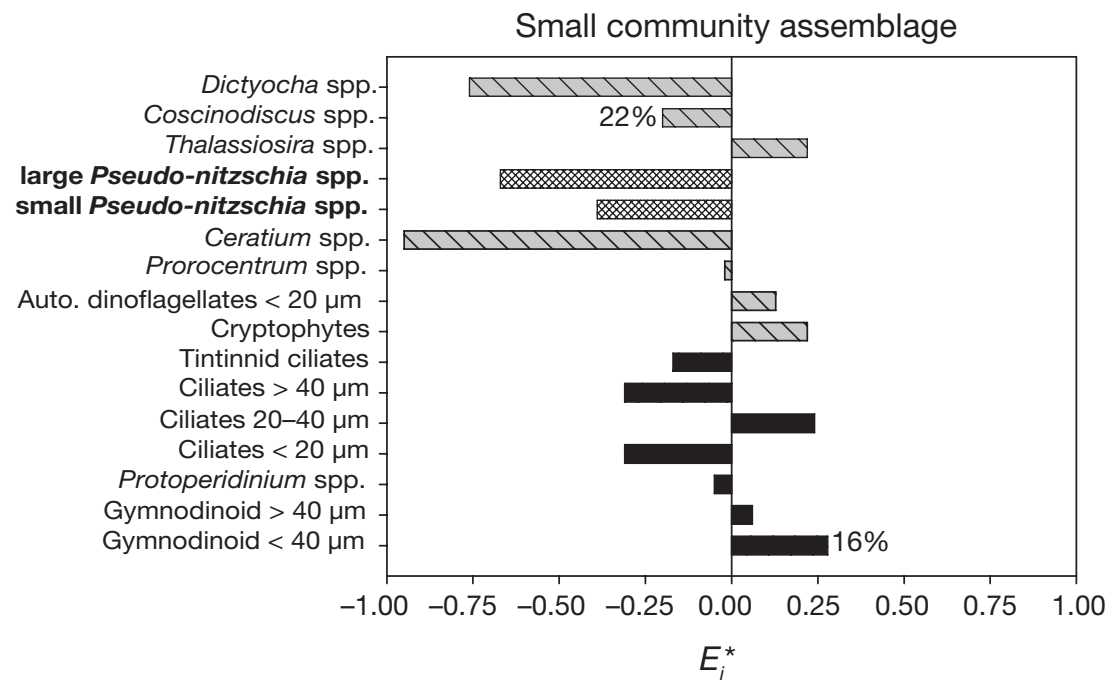

Fig. 9. Small copepod community assemblage. Electivity indices $\left(E_{i}^{*}\right)$ for copepods feeding on natural prey assemblages in Expt 7. Further details as in Fig. 6
$<5 \mu \mathrm{m}$ phytoplankton from grazing. Trophic cascades were not evident on the phytoplankton community $>5 \mu \mathrm{m}$. Additionally, direct estimates of Pseudonitzschia spp. growth did not show evidence of trophic cascades positively affecting their net growth. Likely microzooplankton grazers of the large and dominant phytoplankton Thalassiosira spp., Ceratium spp. and Prorocentrum spp. are the naked heterotrophic dinoflagellates Gyrodinium spp. and the thecate dinoflagellates Protoperidinium spp. Although these 2 heterotrophic dinoflagellate genera were cleared at high rates by all copepods (thus possibly initiating a trophic cascade), their abundance in the plankton was usually low. Additionally, grazing rates on large phytoplankton and, most significantly, on Pseudo-nitzschia spp., by microzooplankton during this study was low compared to their growth rates (Olson et al. unpubl.). Because of this, it is not surprising that trophic cascades were not apparent in the large phytoplankton size class.

The lack of a trophic cascade in the large phytoplankton, specifically the biomass dominants, indicates: (1) that microzooplankton grazing pressure on these large cells is low, and (2) that any structuring mechanisms the copepod population exerts on the large phytoplankton must result from direct grazing. Because we found very little clearance and negative $E_{i}^{*}$ values on the biomass dominants, the ability of these plankton to bloom and dominate the community composition must, in part,

Table 4. Published copepod abundance estimates for the Washington or Oregon coasts, Pseudo-nitzschia spp. production and estimated Pseudo-nitzschia spp. production grazed for each experiment (present study: see 'Materials and methods' for calculations). Numbers in parentheses following mean copepod abundance are sample sizes. Sources were: 1, Postel et al. (1980); 2, Postel et al. (1982); 3, Morgan et al. (2003)

\begin{tabular}{|c|c|c|c|c|c|c|c|c|c|}
\hline \multirow{2}{*}{$\begin{array}{l}\text { Expt } \\
\text { No. }\end{array}$} & \multirow[t]{2}{*}{ Copepod species } & \multicolumn{3}{|c|}{ Copepod abundance $\left(\mathrm{m}^{-3}\right)$} & \multirow[t]{2}{*}{ Source } & \multirow{2}{*}{$\begin{array}{l}\text { Pseudo-nitzschia } \\
\text { production } \\
\left(\mathrm{mg} \mathrm{C} \mathrm{m}^{-3} \mathrm{~d}^{-1}\right)\end{array}$} & \multicolumn{3}{|c|}{$\begin{array}{l}\text { Pseudo-nitzschia } \\
\text { production grazed (\%) }\end{array}$} \\
\hline & & Min. & Max. & Mean & & & Min. & Max. & Mean \\
\hline 1 & Acartia longiremis & 4 & 8033 & $1266(22)$ & 1,2 & 11.04 & 0.02 & 44.0 & 7.0 \\
\hline 2 & Metridia pacifica & 4 & 72 & $25(8)$ & $1,2,3$ & 1.44 & 0.09 & 1.6 & 0.6 \\
\hline 3 & Metridia pacifica & 4 & 72 & $25(8)$ & $1,2,3$ & 0.29 & 0.007 & 0.01 & 0.004 \\
\hline 4 & Acartia longiremis & 4 & 8033 & $1266(22)$ & 1,2 & 0.58 & 0.01 & 22.3 & 3.51 \\
\hline 5 & Calanus pacificus/C. marshallae & e 18 & 291 & $131(8)$ & $1,2,3$ & 5.3 & 0.08 & 1.3 & 0.6 \\
\hline 6 & Metridia pacifica & 4 & 72 & $25(8)$ & $1,2,3$ & 0.44 & 0.02 & 0.41 & 0.14 \\
\hline 7 & Small community & 461 & 22290 & 7045 & 1,2 & 0.09 & 0.7 & 31 & 9.9 \\
\hline
\end{tabular}




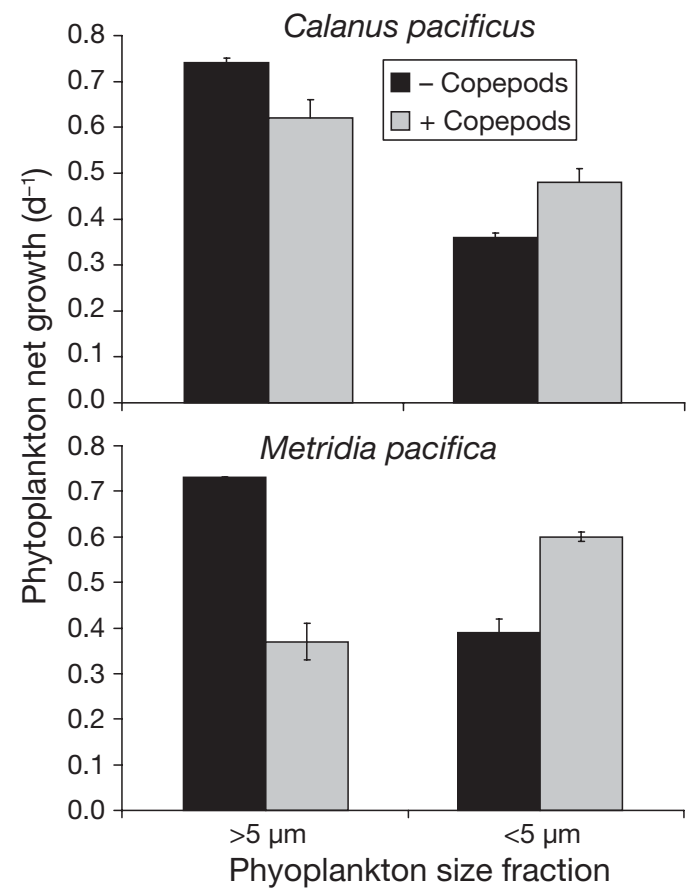

Fig. 10. Mean ( \pm SE) net phytoplankton growth rates for 2 chlorophyll size fractions ( $>5 \mu \mathrm{m}$ and $<5 \mu \mathrm{m}$ ) incubated with or without copepods Calanus pacificus and Metridia pacifica

be due to reduced mortality from copepod grazing. This must especially be the case for Ceratium spp. and Prorocentrum spp., whose intrinsic growth rates are much lower than that of diatoms (Chan 1978).

Finding a consistent pattern of selective grazing by copepods in natural prey assemblages is, by itself, extremely challenging due to the variability associated with grazing experiments. Intrinsic variability can be expected due to the dynamic nature of the Washington coast, where prey populations vary in species composition and biomass concentration on short time and space scales. A grazer's feeding behavior may be shaped by the current and previous prey suite (Uye 1996). Additionally, the grazing behavior of a copepod on a specific prey can be shaped by the copepod's evolutionary history (Colin \& Dam 2002, 2004). Colin \& Dam (2004) show that a population of Acartia hudsonica unaccustomed (i.e. 'naïve') to a diet of the toxic dinoflagellate Alexandrium fundyense exhibited lower somatic growth, size at maturity, egg production and survival compared to populations of A. hudsonica historically exposed to these toxic dinoflagellates. Additionally, they show that when reared on toxic $A$. fundyense, succeeding generations of the naïve copepod populations can increase egg production and ingestion rates, supporting their argument that toxic phytoplankton, specifically $A$. fundyense, can be a selective agent creating genetically distinct populations. However, it is unlikely that the evolutionary his- tory of the copepods we used explains the observed difference in selection between prey types. First, the prey species we examined, including toxic Pseudonitzschia spp., are at times ubiquitous across our study region. Second, unlike the geographically isolated bays from which the copepods were collected in the Colin \& Dam (2004) study, the geography and hydrography of our study region probably precludes continued geographic isolation. Consequently, it is highly unlikely any single selective force (including prey types) would be geographically distinct in our opencoast study site, especially on evolutionary timescales.

Nonetheless, we have clearly shown that, within any given copepod species and experiment, selective feeding occurred, especially on microzooplankton. Our data show that selective feeding behavior, both positive and negative, affect the plankton community composition on the Washington coast. This is exemplified directly by our evidence of trophic cascades reducing mortality in the $<5 \mu \mathrm{m}$ chl a community, and indirectly by indicating that the biomass dominants achieve dominance by being largely omitted from the copepod diet, thus reducing their mortality rates compared to competing phytoplankton.

Pseudo-nitzschia, which is often a numerical dominant, should also be considered as a phytoplankter that benefits from low copepod grazing mortality. Our data highlight how important a reduction in mortality is to a phytoplankter's population ecology. Therefore, increased efforts should be made to study plankton mortality if we are to truly understand the population ecology of influential plankton.

Acknowledgements. We thank W. Cochlan and J. Herndon (Romberg Tiburon Center for Environmental Studies, San Francisco State University) for the nutrient analyses, and V. Trainer and K. Baugh (NOAA/National Marine Fisheries Service) for generously providing the domoic acid data. We thank T. Wood for assistance with microscopy, and the B. Frost laboratory (UW) for the use of plankton nets and for their constructive criticisms throughout this project. The constructive comments of 4 anonymous reviewers improved an earlier version of this manuscript. The assistance we received from the captain and crew of the RV 'Wecoma' was exceptional and without it this research would not have been possible. This study is part of the ECOHAB PNW project and was funded by the National Science Foundation grant OCE-0234587 and by the Coastal Ocean Program of the National Oceanic and Atmospheric Administration (NOAA) (NA17OP2789). This is ECOHAB publication 176 and ECOHAB PNW publication 8.

\section{LITERATURE CITED}

Banse K (1994) Grazing and zooplankton production as key controls of phytoplankton production in the open ocean. Oceanography 7:13-20

Bargu S, Marinovic B, Mansergh S, Silver MW (2003) Feeding responses of krill to the toxin-producing diatom Pseudonitzschia. J Exp Mar Biol Ecol 284:87-104 
Bates SS, Douglas DJ, Doucette GJ, Léger C (1995) Enhancement of domoic acid production by reintroducing bacteria to axenic cultures of the diatom Pseudo-nitzschia multiseries. Nat Toxins 3:428-435

Broglio E, Jónasdóttir SH, Calbet A, Jakobsen HH, Saiz E (2003) Effect of heterotrophic versus autotrophic food on feeding and reproduction of the calanoid copepod Acartia tonsa: relationship with prey fatty acid composition. Aquat Microb Ecol 31:267-278

Calbet A, Landry MR (2004) Phytoplankton growth, microzooplankton grazing, and carbon cycling in marine systems. Limnol Oceanogr 49:51-57

Calbet A, Saiz E (2005) The ciliate-copepod link in marine ecosystems. Aquat Microb Ecol 38:157-167

Chan AT (1978) Comparative physiological study of marine diatoms and dinoflagellates in relation to irradiance and cell size. I. Growth under continuous light. J Phycol 14: 396-402

Colin SP, Dam HG (2002) Latitudinal differentiation in the effects of the toxic dinoflagellate Alexandrium spp. on the feeding and reproduction of populations of the copepod Acartia hudsonica. Harmful Algae 1:113-125

Colin SP, Dam, HG (2004) Testing for resistance of pelagic marine copepods to a toxic dinoflagellate. Evol Biol 18: 355-377

Cowles TJ, Olson RJ, Chisholm SW (1988) Food selection by copepods: discrimination on the basis of food quality. Mar Biol 100:41-49

Cusack CK, Bates SS, Quilliam MA, Patching JW, Raine R (2002) Confirmation of domoic acid production by Pseudonitzschia australis (Bacillariophyceae) isolated from Irish waters. J Phycol 38:1106-1112

Ederington MC, Mcmanus GB, Harvey HR (1995) Trophic transfer of fatty acids, sterols, and a triterpenoid alcohol between bacteria, a ciliate, and the copepod Acartia tonsa. Limnol Oceanogr 40:860-867

Fehling J, Davidson K, Bolch CJ, Bates SS (2004) Growth and domoic acid production by Pseudo-nitzschia seriata (Bacillariophyceae) under phosphate and silicate limitation. J Phycol 40:674-683

Fessenden L, Cowles TJ (1994) Copepod predation on phagotrophic ciliates in Oregon coastal waters. Mar Ecol Prog Ser 107:103-111

Frost BW (1972) Effects of size and concentration of food particles on feeding behavior of the marine planktonic copepod Calanus pacificus. Limnol Oceanogr 17:805-815

Granéli E, Olsson P, Carlsson P, Granéli W, Nylander C (1993) Weak top-down control of dinoflagellate growth in the coastal Skagerrak. J Plankton Res 15:213-237

Hamm CE, Merkel R, Springer O, Jurkojc P, Maier C, Prechtel K, Smetacek V (2003) Architecture and material properties of diatom shells provide effective mechanical protection. Nature 421:841-843

Horner RA (2002) A taxonomic guide to some common marine phytoplankton. Biopress, Bristol

Horner RA, Hickey BM, Postel JR (2000) Pseudo-nitzschia blooms and physical oceanography off Washington State, USA. S Afr J Mar Sci 22:299-308

Huntley ME (1982) Yellow water in La Jolla Bay, California, July 1980. 2. Suppression of zooplankton grazing. J Exp Mar Biol Ecol 63:81-91

Huntley M, Sykes P, Rohan S, Marin V (1986) Chemically-mediated rejection of dinoflagellate prey by the copepods Calanus pacificus and Paracalanus parvus: mechanism, occurrence and significance. Mar Ecol Prog Ser 28:105-120

Irigoien $\mathrm{X}$, Head RN, Harris RP, Cummings $\mathrm{D}$, Harbour $\mathrm{D}$, Meyer-Harms B (2000) Feeding selectivity and egg pro- duction of Calanus helgolandicus in the English Channel. Limnol Oceanogr 45:44-54

Ivlev VS (1961) Experimental ecology of the feeding of fishes. Yale University Press, New Haven, CT, p 19-115

Jones RH, Flynn KJ (2005) Nutritional status and diet composition affect the value of diatoms as copepod prey. Science 307:1457-1459

Kaczmarska I, LeGresley MM, Martin JL, Ehrman J (2005) Diversity of the diatom genus Pseudo-nitzschia Peragallo in the Quoddy Region of the Bay of Fundy, Canada. Harmful Algae 4:1-19

Kiørboe T, Saiz E, Viitasalo M (1996) Prey switching behaviour in the planktonic copepod Acartia tonsa. Mar Ecol Prog Ser 143:65-75

Klein Breteler WCM, Schogt N, Baas M, Schouten S, Kraay GW (1999) Trophic upgrading of food quality by protozoans enhancing copepod growth: role of essential lipids. Mar Biol 135:191-198

Klein Breteler WCM, Koski M, Rampen S (2004) Role of essential lipids in copepod nutrition: no evidence for trophic upgrading of food quality by a marine ciliate. Mar Ecol Prog Ser 274:199-208

Kozlowsky-Suzuki B, Carlsson P, Rühl A, Granéli E (2005) Food selectivity and grazing impact on toxic Dinophysis spp. by copepods feeding on natural plankton assemblages. Harmful Algae 5:57-68

Lechowicz MJ (1982) The sampling characteristics of electivity indexes. Oecologia 52:22-30

Leising AW, Pierson JP, Halsband-Lenk C, Horner R, Postel J (2005) Copepod grazing during spring blooms: Does Calanus pacificus avoid harmful diatoms? Prog Oceanogr 67:384-405

Lessard E, Murrell MC (1996) Distribution, abundance and size composition of heterotrophic dinoflagellates and ciliates in the Sargasso Sea near Bermuda. Deep-Sea Res 43:1045-1065

Lincoln JA, Turner JT, Bates SS, Leger C, Gauthier DA (2001) Feeding, egg production, and egg hatching success of the copepods Acartia tonsa and Temora longicornis on diets of the toxic diatom Pseudo-nitzschia multiseries and the nontoxic diatom Pseudo-nitzschia pungens. Hydrobiologia 453:107-120

Lundholm N, Hansen PJ, Kotaki Y (2004) Effect of pH on growth and domoic acid production by potentially toxic diatoms of the genera Pseudo-nitzschia and Nitzschia. Mar Ecol Prog Ser 273:1-15

MacFadyen AM, Hickey BM, Foreman MGG (2005) Transport of surface waters from the Juan de Fuca Eddy region to the Washington coast: implications for HABs. Cont Shelf Res 25(16):2008-2021

Maldonado MT, Hughes MP, Rue EL, Wells ML (2002) The effect of $\mathrm{Fe}$ and $\mathrm{Cu}$ on growth and domoic acid production by Pseudo-nitzschia multiseries and Pseudo-nitzschia australis. Limnol Oceanogr 47:515-526

Maneiro I, Iglesias P, Guisande C, Riveiro I, Barreiro A, Zervoudaki S, Granéli E (2005) Fate of domoic acid ingested by the copepod Acartia clausi. Mar Biol 148:123-130

Menden-Deuer S, Lessard EJ (2000) Carbon to volume relationships for dinoflagellates, diatoms, and other protist plankton. Limnol Oceanogr 45:569-579

Meyer-Harms B, Irigoien X, Head R, Harris R (1999) Selective feeding on natural phytoplankton by Calanus finmarchicus before, during, and after the 1997 spring bloom in the Norwegian Sea. Limnol Oceanogr 44:154-165

Miralto A, Barone G, Romano G, Poulet SA and 7 others (1999) The insidious effect of diatoms on copepod reproduction. Nature 402:173-176 
Morgan CA, Peterson WT, Emmett RL (2003) Onshoreoffshore variations in copepod community structure off the Oregon coast during the summer upwelling season. Mar Ecol Prog Ser 249:223-236

Nielsen TG (1991) Contribution of zooplankton grazing to the decline of a Ceratium bloom. Limnol Oceanogr 36: 1091-1106

Nival P, Nival S (1976) Particle retention efficiencies of an herbivorous copepod, Acartia clausi (adult and copepodite stages): effects on grazing. Limnol Oceanogr 21:24-38

Parsons TR, Maita Y, Lalli, C. M. (1984) A manual of chemical and biological methods for seawater analysis. Pergamon Press, New York

Postel JR, Peterson WK, Kitchen JC, Menzies DW (1980) Data report of the DOE-sponsored Northwest Marine Sciences Group July-August 1979 cruise. Ref. A80-37. School of Oceanography, University of Washington, Seattle, WA

Postel JR, Peterson WK, Kitchen JC, Menzies DW (1982) Data report of the DOE-sponsored Northwest Marine Sciences Group September-October 1980 cruise. Ref. A82-1. School of Oceanography, University of Washington, Seattle, WA

Rey-Rassat C, Irigoien X, Harris R, Head R, Carlotti F (2002) Growth and development of Calanus helgolandicus reared in the laboratory. Mar Ecol Prog Ser 238:125-138

Rhodes LL (1998) Identification of potentially toxic Pseudonitzschia (Bacillariophyceae) in New Zealand coastal waters, using lectins. NZ J Mar Freshw Res 32:537-544

Roff JC, Hopcroft RR (1986) High precision microcomputer based measuring system for ecological research. Can J Fish Aquat Sci 43:2044-2048

Stehr CM, Connell L, Baugh KA, Bill BD, Adams NG, Trainer VL (2002) Morphological, toxicological, and genetic differences among Pseudo-nitzschia (Bacillariophyceae) species in inland embayments and outer coastal waters of Washington State, USA. J Phycol 38:55-65

Teegarden GJ (1999) Copepod grazing selection and particle discrimination on the basis of PSP toxin content. Mar Ecol Prog Ser 181:163-176

Editorial responsibility: Otto Kinne (Editor-in-Chief), Oldendorf/Luhe, Germany
Teegarden GJ, Campbell RG, Durbin EG (2001) Zooplankton feeding behavior and particle selection in natural plankton assemblages containing toxic Alexandrium spp. Mar Ecol Prog Ser 218:213-226

Trainer VL, Hickey BM, Homer RA (2002) Biological and physical dynamics of domoic acid production off the Washington coast. Limnol Oceanogr 47:1438-1446

Turner JT, Tester PA (1989) Zooplankton feeding ecology: nonselective grazing by the copepods Acartia tonsa Dana, Centropages velificatus Deoliveira, and Eucalanus pileatus Giesbrecht in the plume of the Mississippi River. J Exp Mar Biol Ecol 126:21-43

Uye S (1996) Induction of reproductive failure in the planktonic copepod Calanus pacificus by diatoms. Mar Ecol Prog Ser 133:89-97

Van Dolah FM, Leighfield TA, Haynes BL, Hampson DR, Ramsdell JS (1997) A microplate receptor assay for the amnesic shellfish poisoning toxin, domoic acid, utilizing a cloned glutamate receptor. Anal Biochem 245: 102-105

Vanderploeg HA, Scavia D (1979a) Calculation and use of selectivity coefficients of feeding: zooplankton grazing. Ecol Model 7:135-149

Vanderploeg HA, Scavia D (1979b) Two electivity indexes for feeding with special reference to zooplankton grazing. J Fish Res Board Can 36:362-365

Wells ML, Trick CG, Cochlan WP, Hughes MP, Trainer VL (2005) Domoic acid: the synergy of iron, copper, and the toxicity of diatoms. Limnol Oceanogr 50(6): 1908-1917

Wiadnyana NN, Rassoulzadegan F (1989) Selective feeding of Acartia clausi and Centropages typicus on microzooplankton. Mar Ecol Prog Ser 53:37-45

Wichard T, Poulet SA, Halsband-Lenk C, Albaina A, Harris R, Liu DY, Pohnert G (2005) Survey of the chemical defence potential of diatoms: screening of fifty one species for $\alpha, \beta, \gamma, \delta$-unsaturated aldehydes. J Chem Ecol 31:949-958

Submitted: December 19, 2005; Accepted: March 23, 2006

Proofs received from author(s): October 27, 2006 